\title{
Surface architecture of fungal pathogens
}

\section{Marcio L. Rodrigues*}

Laboratório de Estudos Integrados em Bioquímica Microbiana, Instituto de Microbiologia Professor Paulo de Góes, Universidade Federal do Rio de Janeiro, Rio de Janeiro, Rio de Janeiro, Brazil

${ }^{*}$ Correspondence: marcio@micro.ufrj.br

Surface components in fungal cells include cell wall molecules and, in certain cases, capsular structures (Figure 1) and extracellular matrix components. In pathogens, surface molecules are responsible for key events during interaction with the host (Nimrichter et al., 2005). These events include recognition of pathogens by the immune system and generation of damage to host cells and tissues (Roeder et al., 2004). The molecular diversity of surface structures in fungi is vast and may include (glyco) proteins, polysaccharides, lipids, and pigments (Nimrichter et al., 2005). Many of them have been associated with the antifungal immune response, as well as with steps of fungal adhesion and dissemination during interaction with host cells. For many fungal pathogens, surface composition and architecture are determinant for either disease progression or control (Roeder et al., 2004; Nimrichter et al., 2005; Latgé, 2010; Figueiredo et al., 2011). The diversity of the composition of the cell surface and its molecular architecture are believed to reveal targets for the action of new antifungals, as well as immunogens with potential to interfere with fungal diseases in favor of the host (Nimrichter et al., 2005).

In the Research Topic "Surface Architecture of Fungal Cells," many of the important aspects related to structure and function of surface components of fungi were covered. It was, of course, impossible to discuss the same research topic for each important fungal pathogen. In addition, surface architecture of some of the most important fungal pathogens has been extensively reviewed before (Cassone, 1989; Poulain and Jouault, 2004; Ruiz-Herrera et al., 2006; Chaffin, 2008; Nather and Munro, 2008; Latgé, 2010). We therefore selected a group of pathogens as prototypes for the topic, and this list included Cryptococcus neoformans, Histoplasma capsulatum, Paracoccidioides brasiliensis, Sporothrix schenckii, Pseudallescheria boydii, Aspergillus nidulans, Aspergillus fumigatus, and Colletotrichum gloeosporioides. Components of the cell surface that were discussed in this topic included cell wall and capsular polysaccharides (Frases et al., 2011; Rodrigues et al., 2011; Zaragoza, 2011), peptidopolysaccharides (Lopes-Bezerra, 2011), proteins (Figueiredo et al., 2011; Guimaraes et al., 2011; Puccia et al., 2011), pigments (Zaragoza, 2011), and glycolipids (Barreto-Bergter et al., 2011; Nimrichter and Rodrigues, 2011). In this context, articles in this topic were focused on (i) how fungal molecules are assembled at the cell surface (Guimaraes et al., 2011; Lopes-Bezerra, 2011; Nimrichter and Rodrigues, 2011; Puccia et al., 2011; Zaragoza, 2011), (ii) how they impact

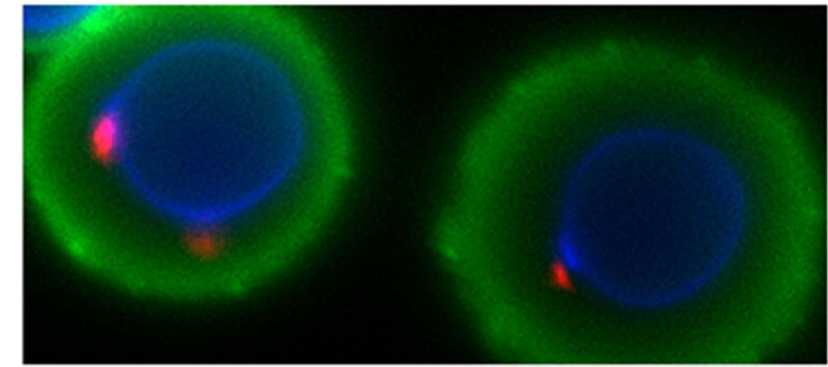

FIGURE 1 | Surface architecture of a fungal pathogen. This image illustrates how some of the surface components of the human pathogen Cryptococcus neoformans are distributed at the cell surface. Cell wall-associated chitin is stained in blue, chitooligomers are stained in red, and capsular polysaccharides are stained in green. Courtesy of Dr. Fernanda L. Fonseca.

the immune response (Figueiredo et al., 2011; Guimaraes et al., 2011; Lopes-Bezerra, 2011; Nimrichter and Rodrigues, 2011; Puccia et al., 2011; Rodrigues et al., 2011), (iii) the role of surface components in fungal physiology (Guimaraes et al., 2011; LopesBezerra, 2011; Nimrichter and Rodrigues, 2011; Puccia et al., 2011; Zaragoza, 2011), (iv) their potential to work as target for preventive or therapeutic agents (Figueiredo et al., 2011; Guimaraes et al., 2011; Lopes-Bezerra, 2011; Nimrichter and Rodrigues, 2011; Puccia et al., 2011; Rodrigues et al., 2011), and (v) how to study structure and function of these molecules (Barreto-Bergter et al., 2011; Frases et al., 2011). The extensive work of each contributor resulted in a clear notion that surface molecules of fungal cells are essential to fungal pathogenesis, physiology, and immune recognition. Essentially, these articles strongly indicate that knowledge on structure and functions of surface molecules in fungi can be translated soon into the discovery of new diagnostic, therapeutic, and preventive alternatives.

\section{ACKNOWLEDGMENTS}

Marcio L. Rodrigues is supported by grants from the Brazilian agencies CAPES, FAPERJ, and CNPq. I am grateful to Dr. Maurizio Del Poeta for encouraging preparation of this Research Topic and to each of the authors that kindly contributed with their views about the architecture of the cell surface of fungal pathogens. 


\section{REFERENCES}

Barreto-Bergter, E., Sassaki, G. L., and De Souza, L. M. (2011). Structural analysis of fungal cerebrosides. Front. Microbiol. 2:239. doi: 10.3389/ fmicb.2011.00239

Cassone, A. (1989). Cell wall of Candida albicans: its functions and its impact on the host. Curr. Top. Med. Mycol. 3, 248-314.

Chaffin, W. L. (2008). Candida albicans cell wall proteins. Microbiol. Mol. Biol. Rev. 72, 495-544.

Figueiredo, R. T., Carneiro, L. A., and Bozza, M. T. (2011). Fungal surface and innate immune recognition of filamentous fungi. Front. Microbiol. 2:248. doi: 10.3389/ fmicb.2011.00248

Frases, S., Viana, N. B., and Casadevall, A. (2011). Biophysical methods for the study of microbial surfaces. Front. Microbiol. 2:207. doi: 10.3389/ fmicb.2011.00207

Guimaraes, A.J., De Cerqueira, M.D., and Nosanchuk, J.D. (2011). Surface archi- tecture of Histoplasma capsulatum. Front. Microbiol. 2:225. doi: 10.3389/ fmicb.2011.00225

Latgé, J. P. (2010). Tasting the fungal cell wall. Cell. Microbiol. 12,863-872.

Lopes-Bezerra, L. M. (2011). Sporothrix schenckii cell wall peptidorhamnomannans. Front. Microbiol. 2:243. doi: 10.3389/fmicb.2011.00243

Nather, K., and Munro, C. A. (2008). Generating cell surface diversity in Candida albicans and other fungal pathogens. FEMS Microbiol. Lett. 285, 137-145.

Nimrichter, L., and Rodrigues, M. L. (2011). Fungal glucosylceramides: from structural components to biologically active targets of new antimicrobials. Front. Microbiol. 2:212. doi: 10.3389/fmicb.2011.00212

Nimrichter, L., Rodrigues, M. L., Rodrigues, E. G., and Travassos, L. R. (2005). The multitude of targets for the immune system and drug therapy in the fungal cell wall. Microbes Infect. 7, 789-798.
Poulain, D., and Jouault, T. (2004) Candida albicans cell wall glycans, host receptors and responses: elements for a decisive crosstalk. Curr. Opin. Microbiol. 7, 342-349.

Puccia, R., Vallejo, M. C., Matsuo, A. L., and Longo, L. V. (2011). The Paracoccidioides cell wall: past and present layers toward understanding interaction with the host. Front. Microbiol. 2:257. doi: 10.3389/ fmicb.2011.00257

Rodrigues, M. L., Nimrichter, L., Cordero, R. J., and Casadevall, A. (2011). Fungal polysaccharides: biological activity beyond the usual structural properties. Front. Microbiol. 2:171. doi: 10.3389/ fmicb.2011.00171

Roeder, A., Kirschning, C. J., Rupec, R. A., Schaller, M., Weindl, G., and Korting, H. C. (2004). Toll-like receptors as key mediators in innate antifungal immunity. Med. Mycol. 42, 485-498.

Ruiz-Herrera, J., Elorza, M.V., Valentin, E., and Sentandreu, R. (2006). Molecular organization of the cell wall of Candida albicans and its relation to pathogenicity. FEMS Yeast Res. 6, 14-29.

Zaragoza, O. (2011). Multiple disguises for the same party: the concepts of morphogenesis and phenotypic variations in Cryptococcus neoformans. Front. Microbiol. 2:181. doi: 10.3389/ fmicb.2011.00181

Received: 29 December 2011; accepted: 16 February 2012; published online: 02 March 2012.

Citation: Rodrigues ML (2012) Surface architecture of fungal pathogens. Front. Microbio. 3:80. doi: 10.3389/ fmicb.2012.00080

This article was submitted to Frontiers in Fungi and Their Interactions, a specialty of Frontiers in Microbiology.

Copyright (๑) 2012 Rodrigues. This is an open-access article distributed under the terms of the Creative Commons Attribution Non Commercial License, which permits non-commercial use, distribution, and reproduction in other forums, provided the original authors and source are credited. 